\title{
The Effects of Organizational Spirituality on Organizational Commitment and Happiness in MBA Expert Managers
}

\author{
Maryam Mahdavi $^{1}$, Fatemehsadat Mousavifard ${ }^{2}$, \& Abdolhossein Ayoubi ${ }^{3}$ \\ ${ }^{1}$ Instructor in Payame Noor University \\ ${ }^{2}$ English Literature Department, Islamic Azad University, Arak, Iran. \\ ${ }^{3}$ Biomedical Engineering Department, Amir Kabir University of Technology, Tehran, Iran Postal \\ code: 7418666486 B.O. Box:445. \\ E-Mail: fsmousavifard87@iau-arak.ac.ir
}

Type of the Paper: Research Paper.

Type of Review: Peer Reviewed.

Indexed in: OpenAIRE.

DOI: http://doi.org/10.5281/zenodo.1248413.

Google Scholar Citation: IJMTS

\section{How to Cite this Paper:}

Mahdavi Maryam, Mousavifard Fatemehsadat, \& Ayoubi Abdolhossein. (2018). The Effects of Organizational Spirituality on Organizational Commitment and Happiness in MBA Expert Managers. International Journal of Management, Technology, and Social Sciences (IJMTS), 3(1), 75-87. DOI: http://doi.org/10.5281/zenodo.1248413.

International Journal of Management, Technology, and Social Sciences (IJMTS) A Refereed International Journal of Srinivas University, India.

(C) With Authors.

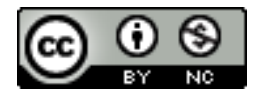

This work is licensed under a Creative Commons Attribution-Non Commercial 4.0 International License subject to proper citation to the publication source of the work.

Disclaimer: The scholarly papers as reviewed and published by the Srinivas Publications (S.P.), India are the views and opinions of their respective authors and are not the views or opinions of the SP. The SP disclaims of any harm or loss caused due to the published content to any party. 


\title{
The Effects of Organizational Spirituality on Organizational Commitment and Happiness in MBA Expert Managers
}

\author{
Maryam Mahdavi $^{1}$, Fatemehsadat Mousavifard ${ }^{2}$, \& Abdolhossein Ayoubi ${ }^{3}$ \\ ${ }^{1}$ Instructor in Payame Noor University \\ ${ }^{2}$ English Literature Department, Islamic Azad University, Arak, Iran. \\ ${ }^{3}$ Biomedical Engineering Department, Amir Kabir University of Technology, Tehran, Iran Postal \\ code: 7418666486 B.O. Box:445. \\ E-Mail: fsmousavifard87@iau-arak.ac.ir
}

\begin{abstract}
This study aims at evaluating the effect of organizational commitment on organizational spirituality and happiness among MBA expert managers south of Iran; it is a descriptive correlational study. This study evaluated 338 participants based on complete count method; participants were MBA expert managers south of Iran. Data were gathered applying Hall and Edwards, organizational commitment Questionnaire of Mowdy, Porter \& Steers and Oxford Happiness Test. Data were analysed by multi-variable linear regression analysis by simultaneous method by SPSS22. Findings indicate that there is a positive relationship between organizational spirituality and its components with organizational commitment and its three aspects and there is a positive relationship between organizational spirituality, happiness and its dimensions. Among different Aspects of organizational spirituality, awareness, instability, perception management and magnification could predict organizational commitment, and awareness, true acceptance and helplessness could predict variable of business managers' happiness.
\end{abstract}

Keywords: Organizational Commitment, Organizational Spirituality, MBA managers of Business companies, Happiness.

\section{INTRODUCTION :}

In today's chaotic world in which organizations are being specialized and continuing their intimate competition, organizations require committed, happy and enthusiastic human force as the most significant component in addition to tools and equipment. The larger the organizations or more their transactions, they need employees to be more committed and more enthusiastic. The more the capital finds improved quality, the possibility of success, improvement and duration of the organization increases more. Its opposite is true; if organizations fail in employing committed, sound and qualified employees, they would be capable of making benefit of other resources such as equipment and primary materials and they must face some problems such as lower efficiency and productivity and consequently fall of the organization.

In this regard, this study aims at evaluating the effect of organizational commitment and happiness on MBA managers of Business companies, working south of Iran; the results seem to assist hospital managers to increase their efficiency and abilities. On the other hand, employees are considered as indexes which evaluate organizations' superiority whose level of loyalty and commitment would cause their duties to be done in higher quality. It will lead better performance, productivity and efficiency (Zaki, 2004).

Different organizational factors can effect on organizational commitment. In fact, organizational commitment is linked to various organizational factors. One of these factors can be spirituality in organizations. Life loses its meaning without job while a desperate job can 
destroy a life; thus, individuals prefer not only to implement spirituality in their personal life, but also in their career and other aspects of life. Spirituality in work environment is a popular discussion in scientific management sources. Indeed, scientific and research centers studied effects of spirituality on style and works (Moghimi et al., 2007).

These days, spirituality is considered as an abstract property in management literature; their effect on significant management functions and organization is under study. Most scholars believe spirituality as a sustainable resource for organization which assists them in achieving efficiency (Zaki,2004).

Scholars believe that motivating spirituality in work environment can include benefits such as increase in trust and organizational commitment, decrease in turnover intention, increase in job satisfaction, innovation, efficiency and motivation. Thus, regarding effects of spirituality and its effects in attitudes and behavior of employees, it seems really significant to study employees' behavior in organization especially service-based organizations. Spirituality in organizations is a structure made of organizational values in culture which increases employees experience via work procedures and facilitates their feeling via communicating with others (Robbins, 2007). One of other factors which effects on spirituality is happiness. Happiness depends on the way of thinking, feeling and individual practice. Individuals who enjoy great amount of happiness possess positive attitude to life while they are ready to face difficulties. They have nice feelings regarding themselves and others and they are committed in their workplace and in their relationships. Happiness is a skill which continuously maintains our satisfaction of present time. In definition of happiness, it is considered as feeling the prosperity, enjoying oneself and having a positive, clear, fun and witty feeling (Chen, 2006).

In fact, happiness is the ability of individuals to be satisfied, enjoy themselves and to be happy (Cohen, 2006). This ability includes satisfaction, a wholesale acquiescence and adores one's life. Happy individuals mostly have relaxed feeling in the workplace and during their leisure activities (Alipour et al., 2007).

Since spirituality is one of human inner feelings and some scholars believe spirituality as warranty for reaching the top levels in cognitiveethical development and as an effort for defining life and replying life questions. Now, this study aims at creating a connection between two variables, organizational commitment and happiness, as two significant features of any organizations.

In a study by Mousa and Ala in Egypt, the relationship between workplace spirituality dimensions (meaningful work, sense of community and organizational values) and organizational commitment approaches (affective, continuance and normative) was investigated. The results of the study showed a strong positive relationship between both meaningful work and sense of community with effective continues and normative commitment (2016).

In another study by Ebrahimi et al., the effect dimensions of spirituality in the workplace on Organization health of security organization the statically population of Sistan and Baluchestan was studied. The results showed that the in three dimensions (work with meaning, sense of solidarity and alignment values) as a spiritual in the workplace that can impact on organizational health transition is by no means the organizational health (2016).

In a study, employees' performance by introducing the construct of Islamic spirituality in the workplace and explore its contribution to the overall development of modern organizations was studied. This study proposed a theoretical framework of Islamic spirituality within the workplace and looks at the effect of Islamic spirituality to predictive employee behavior, with particular emphasis on organizational commitment and organizational citizenship behavior (OCB). This research concluded with a call for researchers to empirically examine the link between Islamic spirituality, organizational commitment, OCB, and job performance (Fares and Noordin, 2016). Based on introduction, this study wants to focus on organizational spirituality variables, 
organizational commitment and happiness of MBA managers of Business companies, working south of Iran with following hypotheses:

- There is a meaningful relationship between organizational spirituality and its components with organizational commitment in MBA managers of Business companies, working south of Iran.

- There is a meaningful relationship between organizational spirituality and its components with happiness of MBA managers of Business companies, working south of Iran.

- Organizational spirituality and its components are able to predict organizational commitment of employeesMBA managers of Business companies, working south of Iran.

- Organizational spirituality and its components are able to predict happiness of MBA managers of Business companies, working south of Iran.

\section{METHODOLOGY :}

This study is an applied descriptive correlational one.

2.1. Statistical Population, Sample and Sampling Method

In this study, statistical population includes all 2600 managers of commercial and business companies located south of Iran in 2016 which were considered as honored managers. Among these managers, 338 individuals were selected as favorite expert managers of MBA companies of south of Iran. Data samples were tested and analyzed by convenience sampling.

\subsection{Data aggregation tools}

In this study, three questionnaires were used which will be explained later.

\subsubsection{Organizational Spirituality Questionnaire of Hall and Edwards}

Hall and Edwards spirituality questionnaire (1986) was designed due to evaluation of spirituality growth, awareness of divinity and quality of relationship with the creator. This questionnaire is a self-reporting one which includes 47 phrases; some of them are of two parts. Participants should express their level of agreement in a 5-point Likert scale.

First version of a test of 5-point scale: awareness, real conception, depression, instability, and magnification were the five scales. In 2002, Hall and Edwards revised the scale and added conception management sub scale to it. Hall and Edwards (1966) evaluated Cronbach's alpha coefficient of sub-scales of spirituality as follows:

Awareness subscale: 0.95, dispersion subscale: 0.90, true acceptance subscale: 0.83, magnification subscale: 0.73, instability subscale: 0.84 , and concept management: 0.77 . These statistics and coefficients indicate an acceptable validity of the test.

\subsubsection{Mowdy, Porter \& Steers' Organization Commitment Questionnaire}

For evaluation of organizational commitment, questionnaire of organizational commitment invented by Mowdy, Porter and Steers in 1979 was used. This questionnaire includes 15 questions, and it covers three aspects: belief in aims and values of organizations, tendency in more attempts along organizations' purposes, tendency in staying in organizations.

Score range is considered as a 5-point Likert scale from 5, totally agree to 1 totally disagree. Since, the applied tool is a standard one, its validity was previously approved by experts. Its reliability which was tested by its creators via Cronbach's alpha,0.90.

\subsubsection{Oxford Happiness Questionnaire}

Oxford happiness questionnaire includes 29 statements and evaluates level of individual's happiness. The theoretical foundation of questionnaire is taken form Argyle and Crosland. They believe it as a structure of three folds to present a functional definition for it: positive emotion, satisfaction level in one cycle, lack of negative feeling.

This test was established in 1989 by Michael Argyle and based on Beck depression questionnaire. 21 phrases are derived from beck depression questionnaire; got reversed; 11 questions were added to cover all other aspects of mental health.

Exactly such as Beck depression test, any statement of the happiness questionnaire includes four choices according to which participants should select any of them based on his own status. Simultaneous validity of questionnaire was calculated 0.43 via evaluation 
of friends. Since happiness is believed to divided to: positive emotion, satisfaction level in one cycle, lack of negative feeling, correlation of this questionnaire was calculated by Bradburn's positive emotion (0.23), satisfaction level in one's life cycle (0.57), and on Beck depression Questionnaire (-0.52). For assessing validity and reliability of Argyle et.al, evaluation of Oxford questionnaire validity was reported by alpha Cronbach's coefficient 0.90 and reliability of retest during 7 weeks was reported 0.78. In Iran, in a study by Alipour and Agah Harris (2007) in order to evaluate validity of Oxford happiness list (Arqil2001), a sample including 142 male and 227 female participants were selected among employees and university students resident of Tehran with the average of 24 years and 11 month in a range of 18-53 years of age in regions of 5, 11, 18, 2 of Tehran (based on four city sections of the North, East, West and the South) and Karaj, Shahriyar, and Islamshahr.

Selected individuals of oxford happiness list completed characteristics questionnaire of Eysenck Personality and Beck depression list. Internal homogeneity of oxford happiness list indicated that all 29 statements were correlated. Cronbach's alpha for the whole list was 0.91. Pearson correlation was respectively $-0.48,0.45$ and -0.39 for oxford correlation list with Beck depression list and extrovert subscales and neuroticism of Eysenck Personality questionnaire which approved convergence and divergence of oxford happiness list.

Factor analysis results with extraction of 5 factors: life satisfaction, individual wellbeing,

\begin{tabular}{|l|l|l|l|l|l|}
\hline sex & Frequency & Percent & Education & Frequency & Percentage \\
\hline Male & 37 & 41.25 & B.A. & 239 & 93.4 \\
\hline female & 219 & 58.75 & M.A. & 17 & 6.6 \\
\hline total & 256 & 100 & Total & 256 & 100 \\
\hline Age & Frequency & percentage & experience & Frequency & percentage \\
\hline$\leq 25$ & 38 & 14.8 & Under 5 & 14 & 5.5 \\
\hline $26-35$ & 89 & 34.8 & $6-10$ & 58 & 22.7 \\
\hline $36-45$ & 91 & 35.6 & $11-15$ & 87 & 34 \\
\hline $45 \geq$ & 38 & 14.8 & $16 \geq$ & 107 & 37.8 \\
\hline sum & 256 & 100 & Sum & 256 & 100 \\
\hline
\end{tabular}

Table1. Frequency Based on Sex, Education and Experience

Based on above table, Pearson correlation coefficient performs as a bridge in establishing a and positive morality could define $49.7 \%$ of total variance with its value more than 1 . Average of Iranian participants score in oxford happiness list (42.07) was different from Argil study (35.6) and findings showed that this questionnaire seems suitable and valid for evaluation of happiness in Iran's society.

In the present study, in order to study validity figurative and conceptual method was used along making sure of a standard questionnaire. Advisor Professors points of view were used to comparison with statistical society. Indeed, in order to approve reliability Cronbach's alpha was used, and the coefficients were $0.91,0.81$ and 0.92 respectively for organizational commitment, happiness and organizational spirituality.

\subsection{Data analysis Method}

For data analysis, statistical methods were used in SPSS22 on descriptive and inference statistical level. To accomplish this goal frequency, percentage, an average and standard deviation were used for descriptive statistics, and in inference step correlational analysis, multiple regression test were used simultaneously. In this section, by making use of Pearson correlation coefficient, multiple regression analysis was used at the same time evaluating study hypothesis.

Hypothesis 1: There is a meaningful relationship between organizational spirituality and its dimensions and organizational commitments and its dimensions. 
commitment and its three dimensions. Thus, according to coefficients study hypothesis is approved; thus, it is possible to say the higher the scores of organizational spirituality, the higher commitment among employees of an **Significance level: 0.01 organization. Study hypothesis is approved true. Hypothesis 2: There is a meaningful relationship between organizational spirituality and organizational happiness and its dimensions

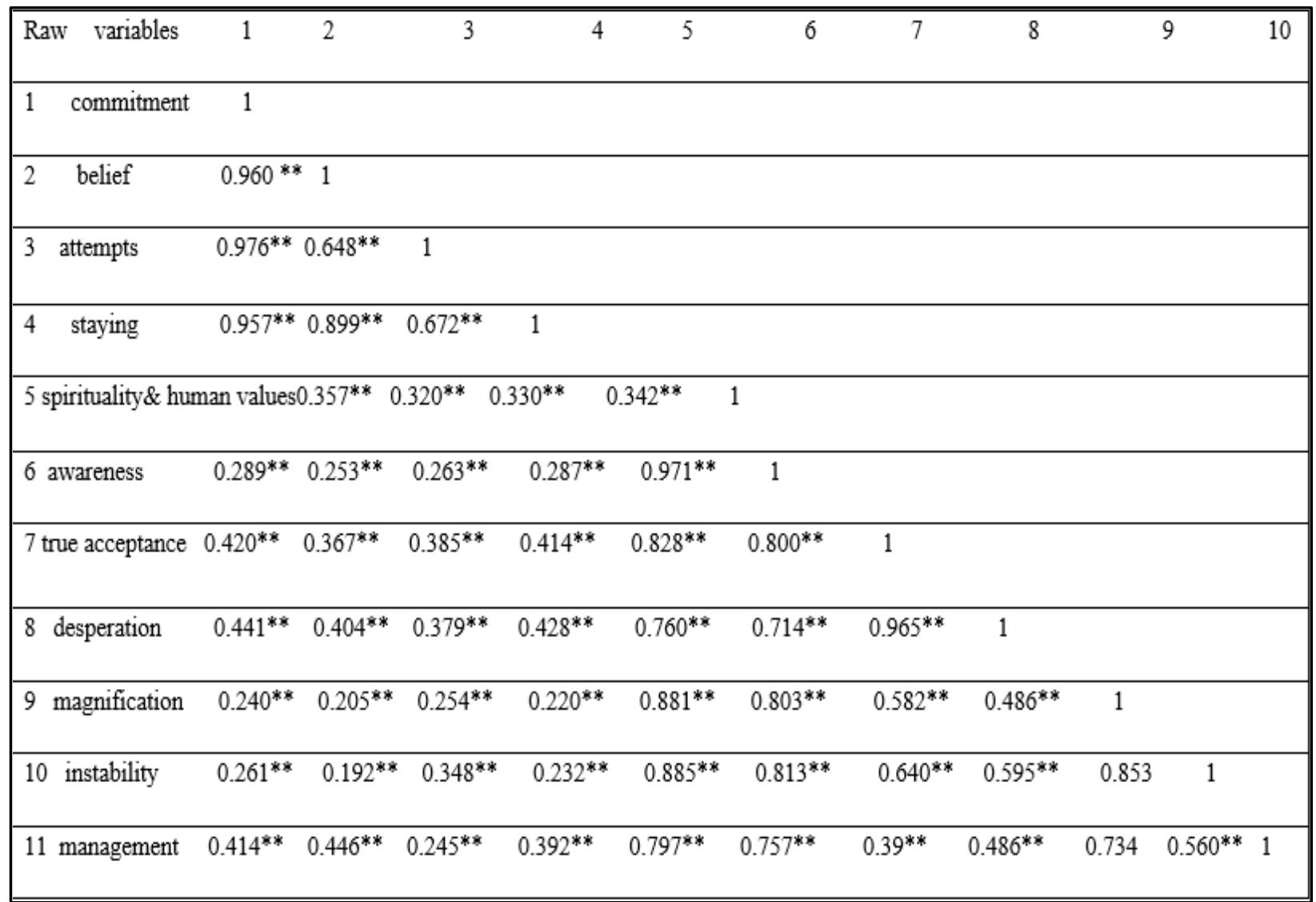

Table 2. Pearson Correlation Coefficient between Organizational Spirituality and Organizational Commitment and their Dimensions

Hypothesis 3: Organizational spirituality and its elements enjoy the ability to predict organizational commitment.

For evaluating the power of prediction of organizational commitment based on organizational spirituality, multiple regressions were used simultaneously. In this analysis, organizational commitment was applied as a variable of organizational spirituality and its dimensions as predicting variables were entered to regression equation. Results are presented in table 4. 
International Journal of Management, Technology, and Social

\begin{tabular}{|c|c|c|c|c|c|c|c|c|c|c|}
\hline Raw variables & 1 & 2 & 3 & 4 & 5 & 6 & 7 & 8 & 9 & 10 \\
\hline 1 happiness & 1 & & & & & & & & & \\
\hline 2 positive emotion & $0.764 * *$ & 1 & & & & & & & & \\
\hline 3 satisfaction & $0.660^{* *}$ & $0.227^{* *}$ & 1 & & & & & & & \\
\hline 4 lack of negative feeling & $0.643^{* *}$ & $0.215^{* *}$ & $0.232^{* *}$ & 1 & & & & & & \\
\hline 5 spirituality \& human values & $0.678^{* 8}$ & $0.325^{* *}$ & $0.412^{* *}$ & $0.696^{* *}$ & 1 & & & & & \\
\hline 6 awareness & $0.666^{* 8}$ & $0.347^{* *}$ & $0.376^{* *}$ & $0.675^{* *}$ & $0.971^{* *}$ & 1 & & & & \\
\hline 7 true acceptance & $0.606^{* *}$ & $0.333^{* *}$ & $0.280^{* 8}$ & $0.647^{* 8}$ & $0.828^{* *}$ & $0.800^{* *}$ & 1 & & & \\
\hline 8 desperation & $0.610^{* *}$ & $0.297^{* *}$ & $0.297^{* 8}$ & $0.687^{* *}$ & $0.760^{* *}$ & $0.714^{* *}$ & $0.965^{* 8}$ & 1 & & \\
\hline 9 magnification & $0.530^{* *}$ & $0.212^{* *}$ & $0.455^{* *}$ & $0.463^{* *}$ & $0.881^{* *}$ & $0.803^{* *}$ & $0.582^{* 8}$ & $0.486^{* *} \quad 1$ & & \\
\hline 10 instability & $0.536^{* 8}$ & $0.162^{* *}$ & $0.432^{* *}$ & $0.579^{* *}$ & $0.885^{* 8}$ & $0.813^{* *}$ & $0.640^{* *}$ & $0.595^{* *}$ & 1 & \\
\hline 11 management & $0.567^{* *}$ & $0.362^{* 8}$ & $0.224^{* *}$ & $0.589 * *$ & $0.797^{* *}$ & $0.757^{* 8}$ & $0.39^{* 8}$ & $0.486 * 0.734$ & $0.560 * 8$ & 1 \\
\hline
\end{tabular}

Significance level: 0.01

Table 3.Pearson Correlation Coefficient for Studying the Relationship between Organizational Spirituality and Its Dimensions with Happiness

Based on table 3, it is clear that from organizational spirituality dimensions, awareness, instability and concept management are at significance level (p 0.000) and magnification at significance level $(\mathrm{p}<0.05)$ can predict organizational commitment variable partially. $\mathrm{R}^{2}$ shows that $33.4 \%$ of organizational commitment changes are justified via awareness, instability, concept management and magnification and based on regression meaningful level $\mathrm{P}_{\text {(regression) }}=0.000$, it is included that the model can be generalized to society.

By the use of results of table 4 regression equation can be explained as:

$\mathrm{Y}-21.162+1.064 \mathrm{X}_{1}+1.313 \mathrm{X}_{2}+1.253 \mathrm{X}_{3}+3.105 \mathrm{X}_{4}$ $\mathrm{Y}$ : organizational commitment; $\mathrm{X}_{1}$ : awareness; $\mathrm{X}_{2}$ : magnification; $\mathrm{X}_{3}$ : instability; $\mathrm{X}_{4}$ : concept management

Thus, based on regression line equation it is concluded that awareness, concept management, instability and magnification variables can predict organizational commitment; thus, this hypothesis is proved.

Based on results, true acceptance and desperation variables had errors above 0.05 and were not suitable for regression equation.
In order to approve results of regression analysis in figure1, prediction of organizational commitment is shown via organizational spirituality and its elements. Based on the figure, significance of prediction ability of organizational spirituality and its elements for organizational commitment; it is positive and it is located on the curve which is a reason for its normal and standard data.

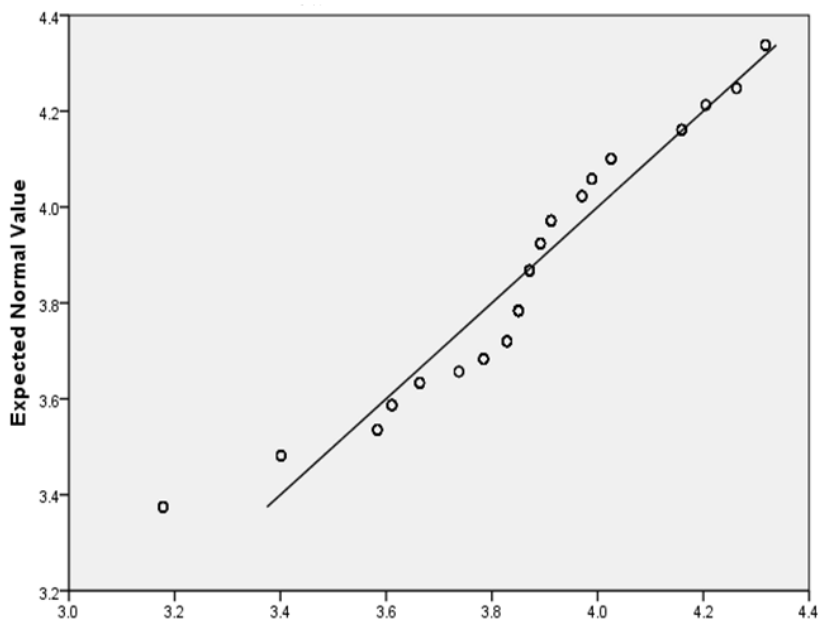




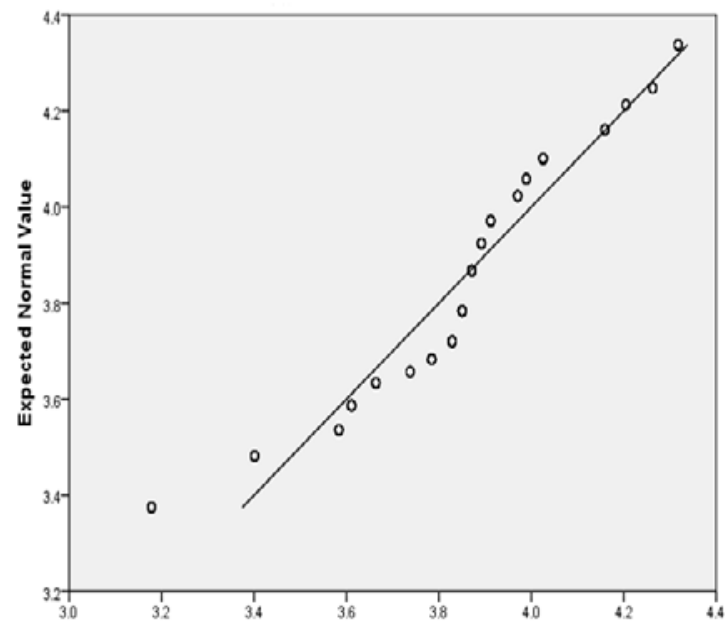

Its Elements

Hypothesis 4: Organizational spirituality and its elements can predict happiness level of employees.

In order to predict happiness of employees based on organizational spirituality and its elements, multi-variable regression was used applying simultaneous method. In this analysis, happiness variable of employees was substituted in the regression equation as scale variable and organizational spirituality and its dimensions as prediction variables. Results are reported in table 4.

Figure1 : Prediction of Organizational Commitment via Organizational Spirituality and

\begin{tabular}{|c|c|c|c|c|c|c|c|c|}
\hline variable & $\begin{array}{l}\text { Predicting } \\
\text { variable }\end{array}$ & B & $\beta$ & $\mathrm{t}$ & $\mathrm{P}($ sig $)$ & $\mathrm{R}^{2}$ & $\bar{F}$ & $\mathrm{dF}$ \\
\hline \multirow[t]{7}{*}{$\begin{array}{l}\text { Organizational } \\
\text { commitment }\end{array}$} & $\begin{array}{l}\text { Constant } \\
\text { coefficient }\end{array}$ & 21.162 & & 5.259 & 0.000 & \multirow{6}{*}{0.334} & \multirow{6}{*}{20.822} & \multirow{7}{*}{6} \\
\hline & awareness & 1.064 & 0.685 & 4.590 & 0.000 & & & \\
\hline & true acceptance & 1.169 & 0.332 & 1.248 & 0.213 & & & \\
\hline & desperation & 0.839 & 0.217 & 0.931 & 0.353 & & & \\
\hline & magnification & 1.313 & 0.315 & 2.356 & 0.019 & & & \\
\hline & instability & 1.253 & 0.373 & 2.849 & 0.005 & & & \\
\hline & $\begin{array}{l}\text { Concept } \\
\text { management }\end{array}$ & 3.105 & 0.664 & 6.996 & 0.0000 & & & \\
\hline
\end{tabular}

Prediction variable: organizational spirituality and human values/ Scale variable: organizational commitment

Table 4. Linear Multiple Regression for Organizational Spirituality and Dimensions

Based on results of table 4, it is clear that among variables of organizational spirituality, awareness, true acceptance and depression at $\mathrm{p}=0.000$ can partially predict happiness of 
employees.

Indeed, $\mathrm{R}^{2}$ Indicates that $52.5 \%$ of happiness changes among employees are defined via awareness, true acceptance and desperation variables; based on significance level of regression $\mathrm{p}_{\text {(regression) }}=0.000$ it is included that the model is applicable to society.

By results of above table it is possible to describe regression line equation:

$\mathrm{Y}=21.242+0.749 \mathrm{X}_{1}+2.683 \mathrm{X}_{2}+3.395 \mathrm{X}_{3}$

$\mathrm{X}_{3}$ : desperation; $\mathrm{X}_{2}$ : true acceptance; $\mathrm{X}_{1}$ :

Awareness; Y: happiness of employees

Thus, studying regression linear equation it can be concluded that awareness, true acceptance and desperation variables from happiness are able to predict employees' happiness which are able to approve this hypothesis.

In addition, based on results, the errors of magnification, instability and management were above 0.05 that's why there were not allowed into regression equation.

In order to approve results of regression analysis in figure 2 predictions of happiness via organizational spirituality and its dimensions. Based on significance figure of prediction ability of organizational spirituality for happiness is presented; it is positive, located on the standard curve; it is of course the reason of data being standard.

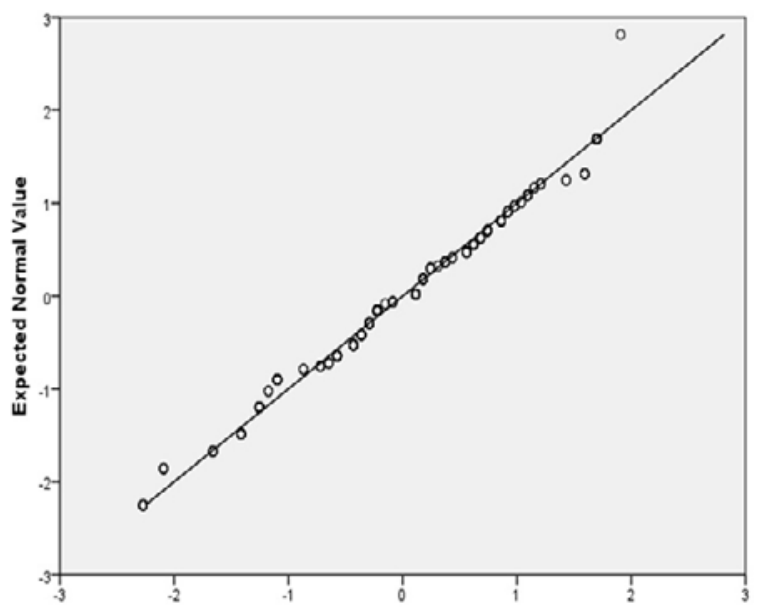

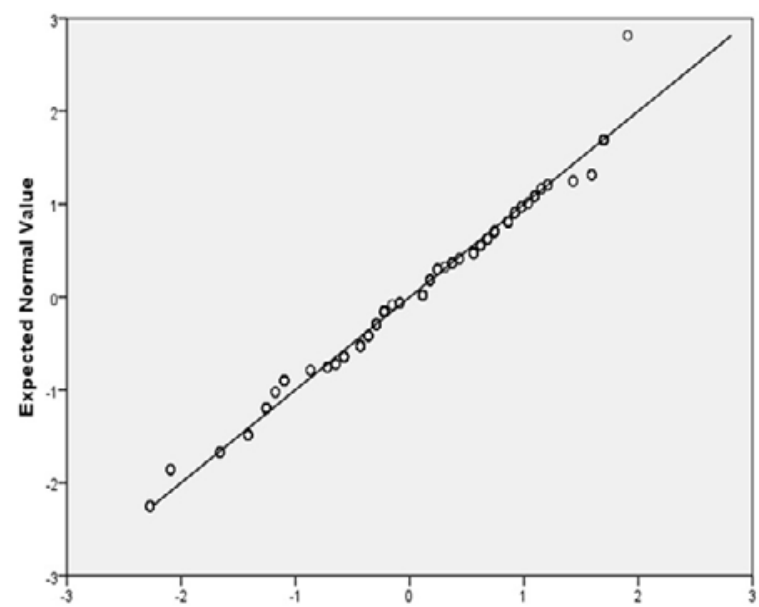

Figure 2 : Prediction of happiness via organizational spirituality and its elements

\section{DISCUSSION :}

Based on results, there is a positive and meaningful relationship among organizational spirituality and all three dimensions of organizational commitment. Therefore based on achieved coefficient, study hypothesis is approved generally.

Scholars believe that spirituality in an organization enjoys 6 scales: awareness, true acceptance, desperation, magnification, instability, and concept management. A combination of these features include spirituality of the individual and indicates that encouraging spirituality in work place can lead some benefits such as individual evolution feeling (Burack, 1999), improved attitude to job such as increased job satisfaction, job participation and decrease in turnover intention (Milliman, et al. 2003), increased occupational consciousness, higher levels of motivation and organizational commitment (Milliman, et al. 2003).

Spirituality increases commitment by an atmosphere developing trust in work environment. Organizational commitment is a concept which seeks to connect employees to employing organization (Mitroff, 2006).

Thus, managers and leaders of organizations establish the feeling among employees and make them feel united with organizations; support each other at the organizations and join 
themselves with missions and purposes. In this case, employees understand their job, meaningful, purposeful and motivating; in other words, motivation is created. There are various evidence indicating that motivated and committed employees make goals achieving possible (Mahdad, 2013).

In fact, organizational commitment is an important motivational issue according which an individual's identity is highly involved in organization; it participates in organization's affairs; involves with them and enjoys its membership. Organizational commitment is degree of psychological simulation and attachment to the organization in which we work.

Organizational commitment is composed of elements: taking organization's values and aims, preparedness for making efforts and for staying a part of organization (Mowdy, Porter \& Steers, 1982). Actually, organizational commitment includes emotional elements such as attachment to job, loyalty to organization and responsibility and firm trust to aims and values which indicate active interest in being a part of organization. As it is observed, it is closely connected to organizational spirituality. Thus, it was predictable to see higher spirituality leads in higher commitment among employees, vice versa. In fact, based on mentioned issues, it is expected to observe organizational spirituality to get connected with organizational commitment.

Based on results, there is a positive and meaningful relationship between organizational spirituality dimensions and dimensions of happiness and it is approved. Literature review indicates spiritual employees are more interested to group activities and are fair and moral communicating with others (Mitroff, \& Denton, 1999; Neck and Milliman, 1994), they show more concern regarding others' needs(Cash,2000); they show more trust, honesty and safekeeping features for organization (Krishna kumar and Neck, 2000); thus spirituality is exhibition of experiences or expression of individual spirit in a dynamic and active process which is representative of God or a divine existence.

On the other hand, happy individuals are those who process information in a $\mathrm{n}$ optimistic and wellbeing path; they analyze data to lead them toward happiness (Chwarz and Strack, 1991).Happiness is an evolution which is performed by the individual to test the self and his life. It includes life satisfaction, positive motifs, elimination of depression and anxiety; its diverse aspects are appeared as cognitions and emotion (Diener, 2002). Based on discussion it is concluded that happiness and spirituality are derived from individuals' inner feelings. Thus, it is clear that there is a positive relationship between these two variables and their components. Results approve this fact. In another word, the higher the spirituality, the more happiness, and vice versa.

In results analysis of this hypothesis, it can be added that when individuals enjoy pleasant feelings, they will give feedback in the best way in the highest commitment.

Pleasant feeling is a great help to mind function and assists individuals in a better understanding of data and making use of decision making rules in complicated views; indeed, enables them to think flexibly. Studies show that happiness and approving feelings will lead to a more positive attitude toward others. It will conduct individuals to move toward the goals in a more optimistic status, to increase their creativity and decision making skills, and consequently to warm up individuals to create inner commitment to accomplish tasks (Diener and Biswas-Diener, 2008).

Indeed, based on the results, it is explicit that among organizational spirituality, awareness, instability and concept management at significance level $\mathrm{p}=0.000$ and magnification at significance level $\mathrm{p} \leq 0.05$ can partially predict organizational commitment variable.

In elaborating this hypothesis, it is possible to announce that spirituality is defined as a human's dimensions that inspires the feeling of existence by features such as nature, inner reinforcement capability, divine abstract experience, elevation of individual to a more developed capacity to love and knowledge, being unified as a whole body with all life aspects and presenting a meaning for existence of individual. Indeed, spirituality is considered 
as a set of values, attitudes and expectations which are connected to superior existence of being and leads individual's life; it is especially related to experiences which approaches individual to uncertainty (Cavendish et al., 2003).

Thus, happiness as internal procedure leads to establishing moral values and cultures and exhibits itself as individuals' behaviors.

Thus, spirituality at work place is accompanied with enjoying the job, being refreshed by the job and receiving meaning and purpose from job (in individual level); being correlated, connected and supported, defining a common goal and set of values (in group level) and performing along organizations' goals and values and being concerned about employees by organization (in organization level) (Fatahi, 2006).

Based on mentioned concepts, spirituality can be considered along the structure of organizational commitment and works to improve it. Since, organizational commitment is non-resident property of the organization which is really significant in organizational behavior and can be defined as individual's power of determination along with collaborating and participating in a particular organization; in other words, organizational commitment is a state in which the individual seeks to keep it and totally it is a positive or negative attitude of employees to the whole organization working in (Groues et al., 2008).

Based on these descriptions, it can be expected that spirituality and its dimensions can make a way for increase in employees' commitment; it is approving the results of this study. It is in agreement with nature and theoretical logic of the effect of spirituality with organizational commitment and its dimensions also with the first hypothesis. In other words, spirituality of employees has a significant and positive organizational commitment and employees with higher degrees of spirituality, enjoy greater amount of organizational commitment.

Based on results, it is obvious that among elements of organizational spirituality, variables of awareness, true acceptance and desperation at significance level of $\mathrm{p}=0.000$ can partially predict variable of employees' happiness.

\section{CONCLUSION :}

It can be said that happiness is based upon attitude and personal comprehension ability; it is a pleasant and delightful state of feeling which originates from positive experiences and life satisfaction (Hills and Argyle, 2001). There are two types of happiness based on psychological point of view; the first one is achieved through marriage life, education, job, financial or welfare facilities which are called concrete happiness. The other type is affected by individuals' inner feelings and personal comprehension which is called mental happiness.

Happiness is an engine creating energy, pleasure and dynamism and it is such as a shield protecting human from stress and problems to grantee mental and physical health (Hills \& Argyle, 2001). Therefore, happiness can be derived from inner and spiritual feeling status of individuals. The present study also indicates the effects of spirituality on happiness of employees.

\section{SUGGESSIONS :}

1. Based on the importance of organizational commitment from attachment and commitment aspects which are felt by employees, more studies should be done on how to provide and develop this feeling in employees.

2. Regarding the significance of the relationship between organizational commitment and employees spirituality it is suggested to hold training classes on how establishing commitment, attachment and spiritual feeling is possible.

3. Based on significance of happiness and spirituality of employees it is suggested to make more efforts to establish intimate atmosphere among employees, employers and managers.

4. In order to promote spirituality, it is suggested to manager to focus on principles such as collaboration, assistance, emotional attention to others, consciousness of working, and inner control of feelings.

\section{REFERENCES :}

[1] Mohamed Mousa and Ruth Ala, (2016) Workplace spirituality and organizational commitment: A study on the public schools teachers in Menoufia (Egypt), African 
Journal of Business Management, 10(10), pp. 247-255, DOI: 10.5897/AJBM2016.8031.

[2] FarangisShahrakiEbrahimi, Mehdi Kazemi, SanjarSalajegheh, (2016) The Effect of Spirituality Aspect in Workplace on Organizational Health(Survey on Social Security in Sistan and Baluchestan).Mediterranean Journal of Social Sciences, 7(3) S3.239-247 Doi:10.5901/mjss.2016.v7n3s3p239.

[3] DjafriFares,Kamaruzaman bin Noordin,(2016) Islamic Spirituality, Organizational Commitment, and Organizational Citizenship Behavior: A Proposed Conceptual Framework, Middle East Journal Of Business, 11(2), 28-34.

[4] Zaki, Mohammadali. (2004). Job satisfaction and organizational commitment among Teachers in Isfahan, Misbah Journal, 13(51).12-23.

[5] Alipour Ahmad and Mojgan Agah Haris(2007). Validity of Oxford happiness List, Iranian Psychologist Periodical, 3(12).56-63.

[6] FatahiMahdi(2006). The effect of spirituality in work place on organizational citizenship behavior and its connection with customers' loyalty and quality of services in Social Welfare Organization.M.A. Thesis in public management. Tehran University: Tehran.

[7] Moghimi, Seyed Mohammad, RahbarAmirhossein and IslamiHasan(2007). Organizational spirituality and its effects on employees innovation; a comparative study. Journal of Morality in Science and technology, 2(3)41-49.

[8] MahdadAli( 2013). Psychology of industry and organizations. Jungle Publication: Tehran.27-28

[8] Benefiel, M. (2003).Mapping the Terrain of Spirituality in Organizations Research.Journal of Organizational Change Management, 16(4), 367-84.
[9] Burack, E. (1999). Spirituality in the workplace. Journal of Organizational Change Management, 12(4), 280-291.

[10] Cash K.C., Gray G.R., \& Rood S.A. (2000).A framework for accommodating religion and spirituality in the workplace. The Academy of Management Executive, 14(3), 124-134.

[11] Cavendish R, Konecny L, Mitzeliotis C, Russo D. (2003). Spiritual care activities of nurses using nursing interventions classification (NIC) labels. International Journal of Nursing Terminologies and classifications, 14: 111-20

[12] Chan, Sow Hup (2006). Organizational identification and commitment of members of a human development organization. Journal of Management Development, 25 (3)

[13] Diener, E; R, Biswas-Diener (2008). Happiness: unlocking the mysteries of psychological wealth, Blackwell Publishing.

[14] Diener,E. (2002). Frequently Asked question (FAQ'S) about subjective wellbeing Happiness and life satisfaction). A printer for report and new comers.available at: http://www./s.psych.uivc .edu/ediener/fag.html accessed on 10 September 2016

[15] Groues, Kevin S. McEnrue, Mary pat, ShenWinny (2008). Developing and Measuring the Emotional intelligence of Leaders. The Journal of Management of Development, 27(2), Bradford.

[16] Hills, P., \& Argyle, M. (2001).Happiness, introversion-extroversion and happy introverts.Personality and Individual Differences, 30, 595-608.

[17] KrishnaKumar, S., \& Neck, C.P. (2002).The "What", "Why", and "how" of spirituality in the workplace. Journal of Managerial Psychology, 17(3), 153-164.

[18] Milliman, J., Czaplewski, A.J. and Ferguson J. (2003). Workplace spirituality 
and employee work attitudes, An exploratory empirical assessment, Journal of Organizational Change Management, 16 (4), 426-447.

[19] Mitroff, I.A., \& Denton, E.A. (1999). A Spirituality Audit of Corporate America: A Hard Look at Spirituality, Religion, and Values in the Workplace, Son Francisco: CA. Jossey-Bass.

[20] Mowdy R.T. Porter L:W\& Steers R.M,(1982). Employee organization. Linking the psychology of commitment, absenteeism and turnover. New York. Academic press.

[21]Neck, C.P., Milliman, J.F. (1994). Thought self-leadership: Finding spiritual fulfillment in organizational life. Journal of Managerial Psychology, 9(6), 292-301.

[22] Robbins A, (2007). Organization behavior. Translation by Parsaian A, Arabi M: Tehran, Published by cultural research Bureau.

[23] Schwarz, N.\&Strack، F. (1991). Evaluating one's life: A judgment model of subjective well-being.In F. Strack، M. Argyle، and N. Schwarz (Eds.). Subjective Well-Being: An Interdisciplinary Perspective. Oxford: Pergamon Press. 